\title{
Medicina tropical e saúde pública na América Latina*
}

\author{
Tropical medicine and \\ public bealth in Latin America
}

\author{
Nancy Leys Stepan \\ Wellcome Unit for the History \\ of Medicine University of Oxford
}

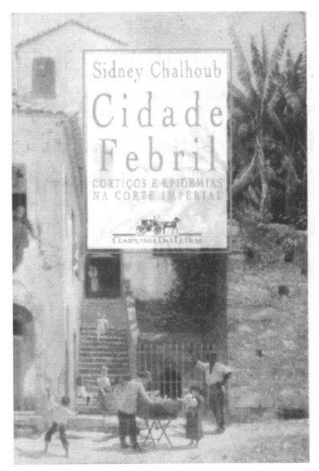

$\mathrm{O}$ interesse pela história da medicina tropical tem crescido muito, em virtude de numerosas injunções políticas e acadêmicas. O imperialismo, por exemplo, voltou a ser objeto de estudos acadêmicos, levando-nos a indagar sobre a importância que os impérios tiveram para a ciência e a medicina, e vice-versa, seguido do estímulo fornecido pelos estudos sobre o período póscolonial, dos quais derivam questões acerca do papel crítico desempenhado pelas colônias na constituição ou genealogia da ciência e medicina nos centros metropolitanos. Problemas contemporâneos também contribuem para o crescente interesse pela história da medicina tropical. A persistência de doenças como a malária, o retorno de 'antigas' doenças, outrora consideradas quase vencidas, como o cólera, assim como o surgimento de novas enfermidades letais, como a causada pelo vírus Ebola, levam-nos a investigar a geografia e scciedtif enty

Sidney Chalhoub Cidade febril: cortrcos eprdemas na corte imperial

Sào Paulo, Companha clas Letras, $1996,250 \mathrm{p}$

Marcos Cueto (org) Salud, cultura $y$ socredad en Amerra Latina nuevas perspectivas historicas Lima, Instituto de Estuclios Peruanos/ Organización Panamericana de la Salud, 1996, $253 \mathrm{p}$. economia política das doenças, bem como os estilos que a medicina tropical ganhou nesses diversos cenários. O cólera e a malária já foram, é claro, doenças comuns na Europa, mas, no início do século XX, tinham sido requalificadas como essencialmente "tropicais". Tal redefinição nos leva a indagar: em que consiste a tropicalidade das doenças tropicais?

Com efeito, o termo 'tropical' não diz respeito apenas à geografia, mas inclui a idéia de que climas quentes e úmidos abrigam diferenças essenciais no tocante a lugares, povos e doenças. A medicina e a saúde pública latinoamericanas encaixam-se com bastante naturalidade nesta concepção difusa de medicina tropical. Apesar disso, os estudos sobre a América Latina guardam certa autonomia em relação aos demais estudos sobre medicina tropical. Uma das razões disso é a relativa defasagem entre o arcabouço colonial e a América Latina. De fato, para muitos historiadores da medicina, medicina tropical é medicina colonial. Embora o conceito de império informal seja encampado pelos estudos latino-americanos, o contexto colonial derivado de estudos sobre a Índia e a África adequa-se mal aos países independentes cla região nos séculos XIX e XX. A medicina do Brasil, por exemplo, continuou a sofrer influência de Portugal após a transferência da Corte de Lisboa para o Rio de Janeiro em 1808. Mas após a independência brasileira, em 1822, a França passou a desempenhar papel muito mais influente na medicina e saúde pública, seguida, em certa medida, pela Alemanha, mais para o fim dos oitocentos, e pelos Estados Unidos, já no século XX. Houve, portanto, centros de referência múltiplos e variáveis.

Desde os primeiros anos de independência política e, sobretudo, após 1840 , quando as revoltas regionais deixaram de ameaçar e a nação começou a se consolidar sob a autoridade de d. Pedro II, os médicos no Brasil procuraram 
definir e valorizar o meio tropical em que viviam, avaliando as possibilidades e limitações que impunha à tarefa de forjar uma civilização nos trópicos. Embora esses profissionais seguissem uma orientação médica européia e fizessem freqüentes viagens de estudo e publicações no velho continente, estavam conscientes de que suas contribuições à medicina eram ignoradas ou apropriadas por outros. Eram, também, alvo da condescendência cultural e racial de parte dos europeus por viverem e praticarem nos trópicos, considerados por estes, em meados do século XIX, como lugares desagradáveis, distantes dos centros de progresso, corrompidos pela insalubridade $\mathrm{e}$ degeneração física e moral. Em certos momentos, o peso do estigma 'tropical' foi grande o suficiente para levar alguns médicos no país a negar a existência de doenças "tropicais" e de uma especialidade médica que pudesse ser chamada de "medicina tropical". É o envolvimento desta com o processo de constituição da nacionalidade que confere interesse especial tanto a esta vertente da medicina quanto à saúcle pública no Brasil. Algo muito semelhante pode ser dito a respeito dos países da Anıérica espanhola.

Tais considerações tornam muito bem-vindos os livros aqui resenhados. Como sublinha em sua informativa introdução Marcos Cueto, o organizador do primeiro, a história da saúde pública e da medicina é, a um só tempo, velha e nova na América Latina. Velha em virtude de antiga tradição de história médica escrita por médicos, tal como na Europa. E nova porque isso deu lugar, nos últimos 15 a vinte anos, a uma história social da medicina, como na Europa, mais uma vez. No âmbito dessa história social, percebemse duas fases na América Latina. A primeira, estruturalista e foucaultiana, foi responsável pela conversão de muitos historiadores e cientistas sociais à medi-cina e saúde pública como campo de estudo. Na segunda fase, as mais valiosas lições do estruturalismo e da teoria da dependência foram absorvidas, mas expurgadas dos exageros e reducionismos anteriores, que relegaram a medicina à condição de mero epifenômeno da economia, e os médicos e funcionários da saúde pública, a simples instrumentos iludidos e ilusionistas do capitalismo. Prevaleceram abordagens mais refinadas sobre como o Estado, a profissão médica e os funcionários da saúde pública definiram e enfrentaram os problemas da doença e insalubridade na região.

Os capítulos do livro de Cueto são um bom reflexo desta tenclência recente na história social da medicina. Exibem alto nível de pesquisa $\mathrm{e}$ redação, são bem documentados, trazem boas referências e argumentos convincentes. ${ }^{1}$ A coletânea se preocupa em abarcar completamente os países (cinco dos vinte países da América espanhola e portuguesa são contemplados, cabendo a parte do leão ao Brasil). Contudo, uma abordagem exaustiva não é possível hoje. Tampouco houve preocupação de articular tematicamente os capítulos. Isso inviabiliza, às vezes, a possibilidade de refletir sobre pontos de semelhança, convergência ou diferença entre os países. Não obstante, uma coleção rica e gratificante resulta da idéia de reunir num único volume as contribuições de alguns dos melhores e mais jovens historiadores da medicina e da saúde pública que tratam atualmente da América Latina.

Ademais, a falta de integração temática do volume é compensada pela conclusão escrita por Cueto e Anne-Emmanuelle Birn: um plano de estudo e ensino em história comparada da saúde pública, envolvendo fontes produzidas na Europa, nos Estados Unidos e na América Latina nos séculos XIX e XX. 
Trata-se de um esforço realmente pioneiro de conectar a América Latina às tendências e aos processos transcorridos em outras partes.

Se esta coletânea for lida junto com o livro de Sidney Chalhoub sobre as febres no Rio de Janeiro no final do século XIX, tem-se material fascinante para assimilar e estimular novas pesquisas. Este é o objetivo modestamente explicitado por Cueto e podemos assegurar que a coletânea atingiu-o plenamente. Muitos historiadores latino-americanos da medicina estão engajados no que já foi chamado de "diálogo unilateral" com estudiosos de outros continentes: lêem, absorvem e criticam o trabalho de historiadores de fora, sem serem lidos por eles. Esperamos que muitos dos autores que colaboraram nos livros aqui analisados encontrem audiência em língua inglesa.

A seguir, organizarei meus comentários em torno de quatro temas interrelacionados que a leitura dos ensaios e capítulos de ambos os livros me sugeriram. O primeiro tema é a política da doença. Refiro-me aos fatores que evidenciam, politicamente, certas crises de saúde, desencadeando intervenções sanitárias ou de outra natureza, mesmo quando as doenças em questão não são relevantes como causas de morte ou morbidade na população geral. O problema é: quem define o 'público' em saúde pública? Em uma situação tipicamente colonial, o público era definido pelo pocler imperial. Na América Latina, prevalecem as políticas de governos regionais e federais associadas à questão mais geral da força ou fragilidade do Estado nacional, já que quase todas as iniciativas em saúde e medicina dele emanavam dela, por causa da relativa ausência de uma classe independente e filantrópica no âmbito da sociedade civil.

O segundo tema é o papel que a ciência médica exerce na modelagem de programas e políticas da saúde pública. Interessa-me, em particular, o impacto da bacteriologia na definição da medicina tropical na América Latina. Foi rápido ou lento? Os métodos bacteriológicos substituíram os programas sanitários mais antigos calcados nas teorias miasmáticas ou no meio ambiente, ou coexistiam com eles, formando interessantes combinações? Como se desenrolou a história da medicina de laboratório na América Latina, e qual a repercussão?

O terceiro tema é o papel das agências internacionais e filantrópicas na medicina tropical latino-americana. Por que a região se tornou território experimental, segundo Cueto, para alguns dos mais ambiciosos e controversos programas de saúde pública implementados pela Fundação Rockefeller no século XX. Em que consistem tais programas? Como as redes informais de poder econômico e político entrelaçando os Estados Unidos e a América Latina serviram à Fundação Rockefeller para negociar seu papel específico na região, e qual o grau de cooperação e conflito presente na relação com as autoridades sanitárias e políticas locais?

O quarto e último tema trata do lugar da identidade étnica e cla raça na medicina e saúde pública: onde e quando foi a raça elemento relevante para estruturar percepções de morbidade e mortalidade na América Latina, como afetou os níveis de ação e inação na saúde pública?

Esses temas encontram seus correlatos na Europa e nos Estados Unidos, onde a história da saúde pública é uma destacada área de estudo. Não obstante, nosso conhecimento de saúde pública nessas regiões ainda sofre de assustadora parcialidade. A eficácia ou o insucesso das intervenções sanitárias em reduzir índices de mortalidade e morbidade; o ritmo com que 
foram implantados os sistemas nacionais ou locais de saúde pública; a medida em que a ciência médica informou as ações em saúde pública; e as maneiras como classe, gênero e identidade étnica afetaram as políticas e seus resultados - todas essas questões continuam a ser debatidas intensamente, mesmo em países como a Grã-Bretanha, onde existe extensa pesquisa na área. ${ }^{2}$ Apliquem essas limitações à América Latina e perceberão as dificuldades que os historiadores enfrentam ao se depararem com o amplo território aberto à investigação. As variações entre os países latino-americanos são muito mais acentuadas do que entre os europeus, ao passo que é muito menor o número de historiadores da medicina voltados para a América Latina.

Detenho-me, em primeiro lugar, na política da doença. Em outras palavras, na política concernente ao que impele o Estado à ação, indagando de seus métodos e efeitos. Vejamos o exemplo do cólera, uma doença que gerou muita discussão entre as autoridades médicas e estatais da Europa no século $\mathrm{XIX}$, como atesta a vasta literatura histórica sobre o assunto. Como na Europa, o cólera foi uma realidade nova para a América Latina no século XIX, considerada a princípio uma doença importada, essencialmente estrangeira à região. Contudo, ao se estabelecer nela, foi absorvida no arcabouço miasmático reinante à época. A contribuição de Lilia Oliver ao volume de Cueto a respeito do impacto das sucessivas epidemias de cólera ocorridas entre 1833 e 1859 em Guadalajara, então a terceira maior cidade do México, mostra que essas epidemias despertaram a consciência da insalubridade da cidade e motivaram algumas medidas sanitárias para minimizar o problema, tal como fizeram as epidemias na cidade de Nova York, no mesmo período. Não obstante os dois livros em questão não tratarem do cólera no Brasil, sua história ilustra os diferentes impactos que as epidemias podem ter em contextos políticos diversos. A maior de todas, em 1855-56, quase não teve efeito na política de saúde pública, embora tenha acarretado cerca de duzentos mil mortes. A avaliação é seguramente subestimada; o número exato de mortos é desconhecido, devido à ausência de dados sobre as causas e variações nos índices de mortalidade. A ausência, por sinal, daquelas vitais estatísticas que se tornaram componente essencial da revolução sanitária na Europa.

A inação frente ao cólera no Brasil teve muitas causas: da debilidade das agências nacionais encarregadas de proteger os portos do país da entrada de doenças até o fato de que o cólera matava principalmente a população negra, pobre e com freqüência escravizada, sem resistência à doença em virtude da subnutrição e das condições extremamente insalubres de vida. Os índices de mortalidade mais elevados concentram-se no Nordeste do país, longe do Rio de Janeiro, o centro do poder nacional. Concomitantemente, a febre amarela adquiria perfil geográfico, demográfico, médico e, sobretudo, político muito diferente, como mostram os estudos realizados por Benchimol, na obra coordenada por Cueto, e Chalhoub em seu livro. A primeira grande epidemia ocorreu em 1849-50. Na década de 1870, a febre amarela já era endêmica e epidêmica na capital federal, estando presente quase que a cada ano na década de 1890 . Ao todo, cerca de sessenta mil pessoas morreram de febre amarela no Rio de Janeiro entre 1850 e 1908 (embora seja preciso utilizar com cautela esses dados provavelmente muito baixos).

No final do século XIX, admitia-se que a febre amarela era uma doença não apenas específica como de origem local, ainda que o modo preciso de transmissão confundisse os médicos. A erradicação da doença foi considerada 
prioritária pelas autoridades políticas no período anterior e posterior à instauração da Primeira República, em 1889, por causa de incidência massiva na capital federal, com elevada mortalidade entre os infectados e, sobretudo, por atingir imigrantes europeus que careciam da imunidade adquirida com os acometimentos da doença na infância. Assim, a febre amarela ameaçava o projeto político de incrementar a imigração européia para o país, de modo a preencher espaços vazios, prover novas fontes de mão-de-obra e, principalmente, 'embranquecer' a população mulata. Esforços esporádicos e, em geral, ineficientes foram então realizados com o objetivo de limpar algumas das áreas mais insalubres da cidade nos últimos anos do século XIX. O caráter politicamente urgente das questões concernentes à raça, à salubridade e ao progresso nacional explicam por que a bacteriologia e a parasitologia vieram a dominar tão rapidamente a saúde pública no país, e por que a erradicação da febre amarela foi a chave da primeira campanha sanitária sistemática na capital, no início do século XX.

A análise de Nísia Trindade Lima e Nara Britto sobre a descoberta pelos médicos dos problemas de saneamento no interior do Brasil confirma a importância da política da doença. As outras análises demonstram como a malária, a ancilostomose e a doença de Chagas acabaram por definir o teor da saúde pública na década de 1920. As três doenças revelaram a suposta inércia e conseqüente falta de produtividade dos trabalhadores rurais num país com uma economia basicamente centrada na agricultura para exportação. De acordo com médicos nacionalistas e reformistas da época, a população rural estava doente e não racialmente degenerada, podendo, portanto, ser salva através de programas de higiene rural (as desigualdades flagrantes na propriedade da terra e empobrecimento da população rural foram, assim, questões contornadas). Embora a análise contida no capítulo de Lima e Britto se apóie em fontes um tanto restritas - em grande parte consistem num periódico médico que durou um ano e que freqüentemente vendia menos de cinqüenta exemplares por edição - , as autoras chamam a atenção para um dos esforços mais interessantes que os médicos brasileiros realizaram, de se organizarem com vistas a promover a instauração de um sistema de saúde pública mais centralizado. Como habitualmente acontecia na América Latina, os resultados deixaram a desejar. Um departamento nacional de saúde mais centralizado foi criado pelo Congresso em 1919, mas seus efeitos na década de 1920 foram limitados, em virtude de a manutenção do poder conferido aos Estados no âmbito da federação para definirem seus próprios objetivos políticos e, ainda, aos escassos recursos alocados à saúde no orçamento federal.

Um último exemplo da política da doença é o esclarecedor estudo de Diana Obregón sobre outra 'descoberta' em saúde pública: a de que lepra constituía um problema nacional na Colômbia em fins do século XIX e início do atual. Seu argumento central consiste em demonstrar como a incidência da lepra foi exagerada por uma geração de jovens médicos daquele país, influenciados pelo anúncio, por Hansen, da causa bacilar da lepra, e ansiosos por afirmar sua própria expertise na nova ciência médica de laboratóro. $\mathrm{Na}$ década de 1920, perceberam que tinham criado uma imagem da Colômbia no exterior de país de leprosos. Lentamente, os médicos começaram a esvaziar o significado da doença, à medida que a Colômbia voltava para uma economia de exportação e mercados externos. Na década de 1930, com 
poucos avanços no tratamento, a lepra era tratada como ameaça muito menor para o país.

O ensaio de Obregón conduz-me ao segundo tema: o impacto das novas ciências microbiológicas na saúde pública latino-americana. Ao longo do século $\mathrm{XIX}$, abordagens que privilegiavam miasmas e fatores ambientais como elementos geradores de doença dominaram a medicina e a saúde pública. Não obstante a América Latina fosse predominantemente 'miasmática' nesses domínios, não sofreu uma revolução miasmática - quer dizer, sanitária no século XIX. A revolução em saúde pública ocorreu apenas na era da medicina laboratorial. Poder-se-ia argumentar que, de fato, este foi o infortúnio da América Latina: ter tido uma revolução bacteriológica antes de uma revolução sanitária adequada. Ainda hoje, mais mortes e doenças são causadas por falta de acesso à água potável e a um sistema de esgotos do que por falta de vacinação.

Pesquisas estão começando a recuperar a história da velocidade com que a bacteriologia e a parasitologia vieram a influenciar as práticas sanitárias na América Latina. Duas contribuições ao livro de Cueto, fornecidas por Julyan Peard e Jaime Benchimol, por exemplo, formam interessantes peças complementares sobre a transição para o modelo microbiológico no Brasil. Juntas revelam quão sintonizados estavam os médicos do país com os últimos avanços na Europa. Mas mostram, também, os diferentes significados que a medicina de laboratório podia adquirir em diferentes circunstâncias históricas.

Peard assina um importante estudo sobre os chamados tropicalistas, designação atribuída a posteriori ao primeiro grupo de médicos a usar no Brasil o laboratório como instrumento de medicina tropical, no período de 1860 a 1890 . Eles buscavam definir a identidade do país como civilização nos trópicos e transformar a saúde em projeto nacional mais consistente. Vivendo numa sociedade escravocrata (o Brasil foi o último país do Ocidente a abolir a escravidão, em 1888), e trabalhando em Salvador (BA), uma das cidades mais negras desse país mulato, os 'tropicalistas' negociaram um meio termo entre as exigências do ambientalismo tropical mais antigo e da nova medicina de laboratório em seus estudos sobre a febre amarela, o beribéri, a filaríose e a ancilostomíase. Conquanto fossem pioneiros na investigação microscópica, preservaram uma estreita relação entre a teoria miasmática, mais antiga, e a nova medicina de laboratório, o que lhes permitiu combinar lugar, clima, fatores sociais e agentes microbianos nas explicações sobre as doenças brasileiras. Sob esse ponto de vista, foram uma geração de transição. Peard mostra que, apesar do caráter inovador de seus trabalhos experimentais, apegavam-se à idéia de que algo especial do meio ambiente brasileiro afetava o curso das doenças, tornando os diagnósticos e as terapêuticas européias equivocados e a experiência brasileira, essencial. Tratase, em suma, de um ótimo estudo de caso sobre os usos do universalismo e particularismo na arena da medicina tropical. ${ }^{3}$

Os tropicalistas permaneceram, contudo, à margem da formulação de políticas nacionais em saúde pública, por serem, em certa medida, marginais à medicina oficial na Bahia, e ainda por ser esta província marginal ao Rio de Janeiro, a capital do império. Era ali que se criavam as políticas nacionais, que se fazia sentir mais intensamente o patronato político e que se encontrava terreno propício ao desenvolvimento da bacteriologia (também no estado de São Paulo, o motor da economia de exportação brasileira no final do século XIX). O estudo pormenorizado de Jaime Benchimol sobre a carreira 
extraordinária do dr. Domingos Freire, o 'descobridor' brasileiro do bacilo da febre amarela, transporta-nos para o mundo acrimonioso, competitivo e, às vezes, farsesco da bacteriologia na década de 1880 , às vésperas do colapso da monarquia e da proclamação da Primeira República. Ao reivindicar a descoberta do 'bacilo' causador da febre amarela, em 1883, Freire recebeu permissão das autoridades sanitárias (por mais espantoso que pareça em retrospecto) para inocular em indivíduos não imunes, na sua maioria imigrantes, sua vacina de valor ainda não comprovado, e isso numa cidade onde a vacinação contra a varíola ainda não era rotina. É um exemplo extremo da política da doença mencionada anteriormente.

Quando a Comissão Reed confirmou a teoria de transmissão da febre amarela pelo mosquito em Havana, em 1900, viabilizando novos métodos de combate à doença através do controle do vetor, o momento de Freire já havia passado. Por haver sido um dos mais conhecidos bacteriologistas do Brasil, com fama na Europa, inclusive, após a sua morte ficou conhecido como o médico pesquisador responsável por um dos mais espetaculares 'erros' científicos cometidos no Brasil. Mas a significação do trabalho dele não reside no emprego equivocado da técnica bacteriológica (erros semelhantes foram cometidos em muitos países da Europa e nos Estados Unidos por bacteriologistas entusiasmados demais com a busca das causas bacilares de doenças, e propensos a anunciar identificações precipitadas). $O$ argumento de Benchimol é que a bacteriologia de Freire e de seus contemporâneos, nas décadas de 1880 e 1890, representou um ponto real de disjunção com o passado, o momento em que as ciências microbiológicas converteram-se na área mais dinâmica da medicina brasileira, em grande parte graças a médicos e teorias posteriormente desacreditados por cientistas do Brasil e no exterior.

A questão, ou enigma, colocada pelo capítulo de Benchimol, ainda que não tenha sido enunciada explicitamente por ele, consiste em saber por que a bacteriologia, ou as ciências microbiológicas, mais genericamente, tiveram impacto tão decisivo no Brasil. Quinze anos após as vacinações de Freire, a primeira campanha sanitária sistemática foi deslanchada na capital federal, sob a liderança de Oswaldo Cruz. Direcionada contra a peste bubônica, a febre amarela e a variola, baseava-se nas novas teorias bacteriológicas e vetoriais de transmissão de doenças. As ciências microbiológicas preencheram, com efeito, um vácuo institucional e político. Os investimentos feitos previamente em saúde pública em âmbito nacional, regional ou local haviam sido, na melhor da hipóteses, escassos. Embora os médicos clamassem repetidas vezes por reformas na educação médica e na saúde pública, suas idéias raramente foram encampadas. Inexistia no Brasil uma categoria forte de funcionários da saúde pública, engajada na medicina social e ambiental e com recursos à disposição. A persistência extraordinária da escravidão é também responsável por isso. Afinal, o Brasil e a maioria dos países latinoamericanos possuíam, há muito tempo, uma classe médica organizada e teorias miasmáticas, mas não tinham experimentado ainda revoluções sanitárias ao longo do século XIX. A conjunção das novas bacteriologia e parasitologia com a inserção do Brasil na economia mundial, a partir da década de 1870, mudou a situação. Pela primeira vez, a saúde tornou-se meta política mais contínua, dados os problemas de produtividade agrícola, a necessidade de imigrantes no contexto da abolição e o crescimento rápido e caótico das 
cidades. Pesava, ainda, a promessa entusiástica feita pela bacteriologia de controlar, mesmo que de forma limitada, os doenças que tinham maior relevância política para o país. Cotejado com o que sabemos sobre o impacto da bacteriologia em outros países da América Latina, na mesma época, o caso brasileiro sugere que talvez tenha sido na 'periferia', e não na Europa, que as novas ciências microbiológicas exerceram impacto mais dramático na organização e no estilo da saúde pública. ${ }^{4}$

O terceiro tema na obra organizada por Cueto é a aplicação desta abordagem bacteriológica/parasitológica às doenças, nas décadas de $1920 \mathrm{e}$ 1930, através das atividades de agências e organizações de saúde internacionais e filantrópicas. Nesse contexto, sobressaía a Fundação Rockefeller. Nos últimos anos, Marcos Cueto produziu vários estudos sobre as atividades desta fundação, chamando a atenção para os complexos fatores técnicos e políticos implicados na reorientação de suas ações dos Estados Unidos para a América Latina, a partir da Primeira Guerra Mundial. ${ }^{5}$ Tais fatores incluíam os sucessos comprovados das novas campanhas sanitárias inspiradas na microbiologia em erradicar doenças específicas, como no caso da febre amarela em Havana; o temor de que a América Latina pudesse ser fonte de infecção ou reinfecção dos Estados Unidos, à medida que se intensificavam os contatos com a região e a imigração dela procedente; e a preocupação com a produtividade dos trabalhadores numa parte do mundo em que os Estados Unidos tinham crescentes interesses econômicos. Deve ser mencionado também o papel de Gorgas, o cirurgião-em-chefe do exército norte-americano e diretor de campanhas contra a febre amarela em Havana e no Panamá: ele também contribuiu para reorientar os interesses da Fundação Rockefeller para o Sul, rumo ao saneamento da América Latina. O ensaio do próprio Cueto é um levantamento muito bem-feito das atividades do Comitê Internacional de Saúde da Fundação Rockefeller na América Latina, visando atingir a completa erradicação de doenças tropicais específicas. ${ }^{6}$ De acordo com sua pesquisa nos arquivos da Rockefeller, esta gastou pouco mais de 13 milhões de dólares na América Latina entre 1913 e 1940, sendo quase a metade em projetos relacionados à febre amarela. Trata-se de uma quantia considerável; em 1922, o orçamento do governo federal brasileiro com a saúde pública totalizava dois milhões de dólares (e fora de apenas $12 \mathrm{mil}$ dólares em 1917). ${ }^{7}$

Cueto mostra que, cada vez que a fundação escolhia uma doença para erradicar, celebrava a ofensiva com entusiasmo, como se fosse oportuniclade excepcionalmente promissora, mas em seguida sobrevinha a desilusão. A crença na possibilidade de eliminar a ancilostomíase foi a primeira a definhar. A erradicação da febre amarela pareceu, à primeira vista, mais viável, exatamente por ser considerada doença das cidades e não das zonas rurais, como a ancilostomíase, mais fácil de administrar, portanto. Contudo, o programa de erradicação foi quase extinto quando a febre amarela ressurgiu em núcleos rurais do interior do Brasil, em 1928. A propósito, a história da vacina de Noguchi contra a febre amarela, introduzida na década de 1920 , forma um contraponto interessante com a de Benchimol sobre a vacina de Domingos Freire, 35 anos antes. Noguchi contava com o apoio e o prestígio da Fundação Rockefeller, e só no fim daquela década se percebeu que sua vacina, baseada na identificação errônea do 'espiroqueta' da febre amarela, não oferecia proteção. A malária foi a terceira doença visada pela Rockefeller. 
A investida principal no Brasil ocorreu em 1938, quando a importação do Anopbeles gambiae da África ocasionou cem mil novos casos da doença e cerca de 14 mil a vinte mil mortes. O rápido emprego de técnicos para exterminar as larvas teve êxito limitado em áreas específicas de infestação, o que revitalizou, por algum tempo, a crença na possibilidade de erradicação completa em outras partes do mundo. Mas isso não iria acontecer.

É difícil avaliar os resultados dos esforços feitos pela Fundação Rockefeller na América Latina. Com certeza, conseguiu chamar a atenção para as condições insalubres de vida das populações pobres da região e desviou a atenção das autoridades sanitárias latino-americanas da França - tradicional matriz de modelos para a medicina e a saúde pública - para os Estados Unidos, apesar das limitações deste país. Tais limitações se revelaram, sobretudo, nas campanhas autoritárias conduzidas de cima para baixo, contra uma única doença, normalmente de curta duração, sem levar em conta as causas econômicas e sociais mais intratáveis de morbidade e mortalidade.

As tensões e os conflitos entre diferentes modelos de saúde pública na América Latina são revelados na análise de Anne-Emmanuelle Birn sobre o trabalho executado pela Fundação Rockefeller no contexto politicamente tenso do México pós-revolucionário, onde os planos originais da instituição se modificaram gradualmente para dar conta de objetivos políticos e sanitários diferentes.

Todos os autores que participam da obra coordenada por Cueto dedicamse à história médica da medicina ou foram treinados nessa área. Já em Cidade febril, Sidney Chalhoub aborda seus temas do ponto de vista do historiador social, que às vezes constata com surpresa o quanto a retórica da medicina e da higiene pública se entrelaça com o projeto político de culpar os pobres por suas doenças, inclusive mascarando-o com freqüência. Embora seja um tema familiar à história da saúde pública, neste livro é analisado no contexto menos conhecido do Brasil de final do século XIX, e de uma maneira que nos leva de volta à política da doença com que iniciei esta resenha. Num trabalho curto, composto de três capítulos, Chalhoub analisa, primeiro, a destruição sem sentido de um dos maiores cortiços do Rio de Janeiro, em 1893 , sob a alegação de que era fonte miasmática de infecções febris na cidade. Sem sentido porque se limitou a empurrar os habitantes daquele cortiço para outros mais distantes do centro urbano, onde políticos e empresários disputavam oportunidades para construir à medida que a cidacle se expandia rapidamente. A destruição dos cortiços tinha, portanto, causas múltiplas; acontecia esporadicamente, fornecendo a higiene um verniz superficial para o que era questão de polícia e dinheiro. Mas o uso da higiene no discurso da política prenunciava o que viria a ocorrer, em escala maciça, no início do século XX, quando o Rio de Janeiro foi reconstruído e embelezado em nome do saneamento e do progresso urbano.

No segundo capítulo, Chalhoub analisa a atenção especial que foi dispensada à febre amarela a partir da década de 1870 , e no terceiro, a resistência à vacinação antivariólica. ${ }^{8}$ Este último é o mais inovador, ao chamar a atenção para o papel das crenças populares e da religião na saúde pública. A revolta contra a vacinação antivariólica compulsória no Rio de Janeiro, em 1904, é um episódio bastante conhecido tanto na história política como na da saúde pública do Brasil. Esta não era a primeira vez que se tentava tornar a vacinação obrigatória, mas era a primeira vez que se envidava sério esforço 
para executar tal decisão, usando o poder, a autoridade e os recursos do governo federal. A sublevação popular que irrompeu contra a vacina antivariólica foi, contudo, tão séria que o Congresso decidiu revogar a obrigatoriedade, já que a insatisfação ameaçava a meta política ainda mais importante de erradicar a febre amarela. Esta foi, efetivamente, eliminada em 1908; a varíola, não. Chalhoub estima que, no final da campanha sanitária, apenas $10 \%$ da população do Rio de Janeiro tinha sido vacinada. E este foi o percentual mais alto a que chegara desde o século passado. Em 1909, a cidade sofreu um dos piores surtos de variola de sua história, no qual milhares de pessoas morreram, principalmente pobres, em grande parte por causa do fracasso do projeto de vacinação.

Dos historiadores que se debruçaram sobre a questão da variola no Brasil, a maioria enfatizou a resistência dos militares positivistas, que encaravam a obrigatoriedade em saúde pública como transgressão intolerável ao direito do indivíduo à liberdade. No entanto, como os residentes mais pobres da cidade normalmente não desfrutavam desse direito, outros historiadores têm procurado novas explicações para a rejeição popular à vacinação antivariólica: a irritação intensa da população com a invasão de seus lares por inspetores sanitários, a desconfiança que nutriam em relação aos médicos e ao Estado, os temores relacionados à eficácia da própria vacina e, especialmente, o medo da polícia e dos tribunais que eram convocados para impor o saneamento. Tais temores não eram desprovidos de racionalidade, e tinham contrapartida na resistência à vacinação em outras partes do mundo.

Chalhoub, contudo, desencava outra fonte de resistência popular entre os pobres do Rio de Janeiro, a saber, sua persistente adesão a um método alternativo de controle da varíola, a variolização. Para o autor, esta era associada à religião afro-brasileira, que a classe política, ansiosa por vender a imagem do Brasil como civilização européia nos trópicos, desejava reprimir por ser um sinal visivel demais das origens africanas da cultura popular do país. Sob esse ponto de vista, a resistência à vacinação expressava profundas clivagens de classe, raça e cultura na sociedade brasileira. Chalhoub reconhece que especula sobre a extensão que a prática da variolização tinha nas décadas que antecederam a revolta contra a vacina. Portanto, seus efeitos sobre a incidência real da varíola não podem ser avaliados. Não obstante, seu ensaio constitui exploração muito interessante dos diferentes significados-culturais, religiosos, políticos - que a doença pode ter no seio de grupos sociais diversos. Acrescenta até então inexplorada a nossa compreensão do abismo sócio-cultural que separava os pobres das autoridades sanitárias na virada do século.

Chalhoub chama a atenção para o impacto do racismo na história da medicina e da saúde pública, e este é o último tópico de minha resenha. $O$ autor contrasta, por exemplo, a grande atenção dispensada à febre amarela por médicos e políticos, nas três últimas décadas do século XIX, em decorrência da relação entre a doença e a imigração de brancos, com a negligência, na mesma época, com que foi tratada a tuberculose, doença de significação muito maior para a população pobre e negra da cidade. Não resta dúvida de que Chalhoub tem razão ao enfatizar o racismo enraizado na medicina e saúde pública oficial do Brasil. Já há muito tempo, este país tem se apresentado ao mundo exterior como "democracia racial", destituída das agudas cisões raciais que caracterizam seu poderoso vizinho do Norte, os Estados Unidos. Mas, na realidade, o Brasil mal pode se qualificar como democracia formal ao 
longo de quase toda a sua história, e a mitologia da harmonia racial não pode esconder o fato de que os pobres são pobres principalmente por serem negros.

Ainda assim, ao contrastar as providências tomadas contra a febre amarela e a tuberculose no Brasil, Chalhoub talvez superestime o poder dos higienistas e subestime as dificuldades que a maioria dos países teve para encontrar soluções adequadas para as doenças decorrentes de pobreza e miséria, como a tuberculose. Os métodos mais bem-sucedidos de controle da tuberculose na época envolviam técnicas sociais, como a notificação compulsória, o isolamento rigoroso e as desinfecções que teriam provocado os mesmos tipos de resistência que a vacinação suscitou, dadas as profundas divisões e desigualdades sociais, econômicas e raciais existentes na sociedade brasileira. A melhoria das condições de vida para a maioria da população, que historicamente tem sido o meio mais eficiente de reduzir a tuberculose, não era, e ainda não é, projeto político do Estado. A tuberculose era tão vulnerável aos preconceitos e estereótipos de raça e nacionalidade quanto outras doenças, como também demonstra Diego Armus, de forma muito clara, em sua contribuição à coletânea de Cueto, num ensaio sobre o modo como à doenças, veio a ser tardiamente erigida em questão de saúde pública na Argentina, no início do século, aproximadamente à mesma época que na Europa.

Historicamente, a saúde pública, com frequiência, tem sido conquistada à custa de práticas que invadem ou transgridem os direitos individuais à privacidade e à liberdade de ação. Portanto, o sucesso das intervenções nesse domínio (exceto sob governo militar ou autoritário) quase sempre dependeu da aceitação por parte da população de que os riscos e as inconveniências das medidas sanitárias são compensadas pelas vantagens que proporcionam. Os estudos históricos exigem de nós atenção para questões de poder social e estatal, direitos de cidadania, legitimidade médica, cooperação e reciprocidade comunitárias e, assim, podem nos dizer muitas coisas sobre por que e quando têm êxito ou fracassam as intervenções em saúde pública. Os ensaios aqui analisados nos ajudam a entender melhor essas questões na América Latina, sugerindo ao mesmo tempo novas oportunidades para investigações futuras.

Tradução de Maria Beatriz de Mello e Souza

- Publicada também em Medical History, January, 1998, 42, pp. 104-112

\section{Notas}

${ }^{1}$ As notas de rodapé da introdução de Cueto fornecem referências de muitos outros estudos recentes na história da saúde pública e da medicina na América Latina, constituindo valioso guia para pesquisa.

${ }^{2}$ A pesquisa comparativa é importante e rara. Excelente contribuição para a história da saúde pública em muitos países (exceto os da América Latina) é o livro de Dorothy Porter (org.) The bistory of public bealth and the modern state, Amsterdam/Atlanta, Georgia, Editions Rodopi B. V., 1994. Os autores examinam os variados graus cle institucionalização da saúde pública, assim como as descontinuidades, paralisias e hesitações reveladas nas práticas sanitárias.

${ }^{3}$ Ver Julyan Peard, 'Tropical disorder and the forging of a Brazilian medical identity, 1860-1890', Hispanic American Historical Review, 77, 1:1-44, 1996.

${ }^{4}$ Para outro exemplo, ver Marcos Cueto, 'Tropical medicine and bacteriology in Boston and Peru: studies of carrion's disease in the early twentieth century', Medical History, 40: 344-64, 1996. 
${ }^{5}$ Ver, especialmente, Marcos Cueto (org.), Missionaries of science: the Rockefeller Foundation and Latin America, Bloomington, Indiana, Indiana University Press, 1994; e, do mesmo autor, 'Sanitation from above: yellow fever and foreign intervention in Peru, 1919-1921', Hispanic American Historical Review, 72, 1: 1-22, 1992.

${ }^{6}$ Uma versão cleste artigo em língua inglesa encontra-se em Cueto (org.), 'Visions of science and development. the Rockefeller Foundation's Latin American surveys of the 1920's', Missionaries of Science, pp.1-22.

7 Dados de Steven Williams, 'Nationalism and public health: the convergence of Rockefeller Foundation technıques and Brazilian fecteral authorty during the timeof yellow fever, 1925-1930', em Cueto (org.), Missionaries of science, pp. 23-51.

${ }^{8}$ Chalhoub publıcou o capítulo sobre febre amarela em inglês; ver 'The politics of disease control yellow fever and race in nineteenth century Rio de Janeiro', J. Lat. Amer. Stud., 25: 441-63, 1993.

\title{
Enciclopédia das raças brasileiras
}

\author{
Encyclopedia of brazilian races
}

\author{
Rober to Motta \\ Professor de antroplogia da Universidade \\ Federal de Pernambuco \\ Rua Santos Elias, 104/708 \\ 52020-090 Recife - Pe
}

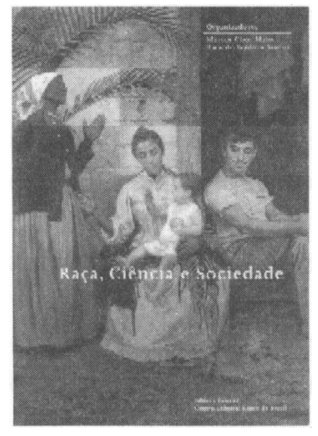

Marcos Chor Maro e Ricarclo Ventura Santos (orgs )

Raça, Ciêncta e

Soctedade

Editora Fiocruz, 1996 PP 252
S e compreendermos antropologia justamente como o estudo de raça, $S$ ciência e sociedade, a antropologia brasileira o que, apesar do que possam dizer teóricos de várias orientações, teria como marco inicial certo artigo do naturalista alemão Karl von Martius, publicado em 1845 no Jornal do Instituto Histórico e Geográfico Brasileiro, "no qual argumentava que, para se escrever a história clo Brasil, era premente abordar as características das três raças que o compunham" (p. 9). Para o estudo desse e de outros marcos iniciais está voltado o artigo que abre o livro em questão, a cargo de John Manuel Monteiro, 'As raças inclígenas no pensamento brasileiro do Império' (pp. 15-22). Destaquemos a atuação de João Baptista de Lacerda Filho (1882, pp. 6-7, 20), várias vezes mencionado neste artigo e no de Giralcla Seyferth, ainda que nenhum antropólogo brasileiro da atualidade, nem sequer os do Museu Nacional, no qual trabalhou, o reivindicasse como antepassado intelectual. Através de muitas medições de crânios e índices do mesmo naipe, Lacerda chegaria à conclusão de que "o nosso indígena, mesmo civilizado, não poderia produzir a mesma quantidade de trabalho útil, no mesmo tempo que os indivíduos de outras raças, especialmente da raça negra... . Eis aí como de um problema antropológico deduz-se um problema econômico e inclustrial." Apesar da falta de progênie reconhecida deste ilustre pesquisador, muitos laivos de sua teoria vão ser encontrados em Gilberto Freyre e noutros autores de nossas ciências sociais, mais africanófilos que indianófilos.

Não poderia faltar em coletânia patrocinada pela Casa de Oswaldo Cruz (COC) o artigo 'Condenado pela raça, absolvido pela medicina: o Brasil descoberto pelo movimento sanitarista da primeira República' (pp. 23-40), redigido por Nísia Trindade Lima e Gilberto Hochman. A frase conhecida por todo adolescente da década de 1950 - "O Brasil é um imenso hospital" — foi 